\title{
PENGEMBANGAN METODE STRESSED SHEETING WELD PADA PENGELASAN PLAT BERPENGUAT DENGAN VARIASI TEMPERATUR PREHEAT
}

\author{
Yustiasih Purwaningrum $^{(1)}$, Triyono ${ }^{(2)}$, Kelvin Koharto ${ }^{(3)}$, Adit Suhartanto ${ }^{(4)}$ \\ Jurusan Teknik Mesin Fakultas Teknologi Industri, Universitas Islam Indonesia ${ }^{(1,3,4)}$ \\ Jurusan Teknik Mesin Fakultas Teknik, Universitas Sebelas Maret Surakarta ${ }^{(2)}$ \\ email:yustiasih2003@yahoo.co.nz $z^{(1)}$,triyonomesin@uns.ac.id ${ }^{(2)}$
}

\begin{abstract}
This research investigates stressed sheeting welded (SSW) effects of stiffened thin plate structure with preheat temperature variations. Stiffened thin plate structure is a structure that consists of frame and sheet that used on vehicle structure because of requirement low volume materials. The principle of SSW is installation of sheeting on the frame is done by pulling the sheeting in hot conditions so the sheeting after joined with the frame has the flat surface. Lap joints of SS 400 with thickness of $1 \mathrm{~mm}$ dan $3 \mathrm{~mm}$ were made using Gas Metal Arc Welding. The preheat temperature that used were $50^{\circ} \mathrm{C}, 60^{\circ} \mathrm{C}$ and $70^{\circ} \mathrm{C}$. The mechanical properties were measured with respect to strength and hardness while physical properties were examined based on the distortion, micro and macrostructure. Results show that the distortion of weld metal with preheat temperatures $50^{\circ} \mathrm{C}, 60^{\circ} \mathrm{C}$ and $70^{\circ} \mathrm{C}$ are $1.02 ; 2.06$; and $2.22 \mathrm{~mm}$ respectively. This values is better than weld metal without $S S W$ that has distortion $3.02 \mathrm{~mm}$. The tensile strength of weld metals with SSW method is $20 \%$ higher than the weld metal without SSW. Ferrite and pearlite structure appeared in based metal and HAZ region while weld metal had acicular ferrite and grain boundary ferrite structure.
\end{abstract}

Keywords : SSW, distortion, strength, microstructure, stiffened thin structure, gas metal arc welding.

\section{PENDAhUluan}

Struktur plat tipis berpenguat yaitu struktur yang terdiri dari plat yang tebal (frame) disambung dengan plat tipis (sheeting), merupakan struktur yang sering digunakan sebagai struktur kendaraan karena mempunyai volume dan berat rendah tetapi kekakuannya baik. Penyambungan dilakukan dengan pengelasan yang menghasilkan distorsi.

Distorsi terjadi karena gradien temperatur pada bagian yang dilas dengan bagian yang tidak dilas sangat besar sehingga tegangan termal dan pemuaian tidak seragam (Radaj, 1992).

Untuk mengurangi distorsi dilakukan proses reforming, tetapi proses mempunyai kelemahan yaitu membutuhkan tambahan investasi waktu, biaya dan tenaga kerja serta dapat mengurangi ketahanan korosi (Triyono, $d k k, 2005)$.
United States Patent no. 6.861.617 merupakan temuan berupa Transient Thermal Tensioning untuk pengelasan sambungan $\mathrm{T}$ dengan 2 pemanas diletakkan di samping dan berjalan bersama - sama elektroda mengelas pada masing - masing sisi sambungan (Dull, $d k k, 2005)$.

Distorsi angular pada pengelasan elektroda dipengaruhi oleh parameter masukan panas, jarak antar elektroda, rasio masukan panas antara elektroda yang satu dengan elekroda yang lain dan kecepatan pengelasan. Parameter yang paling berpengaruh adalah jarak elektroda dan rasio masukan panas (Okano, dkk, 2006).

Penelitian yang dilakukan oleh Deo dan Michaleris (2002) mendapatkan hasil bahwa hibrid antara penjepit dan pemanas sekunder pada sambungan $\mathrm{T}$ dengan ketebalan $1 / 8$ inch menghasilkan sambungan las tanpa distorsi dan bowing. 
Sehingga penting untuk mengembangkan metode untuk memperbaiki karakteristik distorsi pada plat tipis berpenguat.

Pengembangan metode stressed sheeting weld ini menggunakan prinsip pemasangan sheeting pada frame yang dilakukan dengan menarik sheeting dalam keadaan panas sehingga permukaan sheeting rata setelah disambungkan dengan frame.

\subsection{Las GMAW (Gas Metal Arc Welding)}

Pada pengelasan GMAW, logam induk mengalami pencairan akibat pemanasan dari busur listrik yang timbul antara ujung elektroda dan permukaan benda kerja. Elektroda mengalami pencairan bersama-sama dengan logam induk yang menjadi bagian kampuh las. Sebagai pelindung oksidasi dipakai gas pelindung yang berupa gas mulia yaitu 97\% Argon atau Helium sehingga hasil pengelasan tidak menghasilkan terak. (Wiryosumarto, 2000)

\subsection{Distorsi}

Distorsi adalah perubahan dimensi pada struktur las yang terjadi karena pengaruh tegangan thermal saat pengelasan. Klasifikasi distorsi menurut Wiryosumarto (2000) pada hasil las yaitu:

a. Penyusutan tegak lurus garis las (transverse shrinkage).

b. Penyusutan searah dengan garis las (longitudinal shrinkage).

c. Penyusutan sudut berupa rotasi terhadap garis las (angular shrinkage).

\section{METODE PENELITIAN}

\subsection{Bahan dan Proses Pengelasan}

Material yang digunakan adalah plat baja karbon SS400 tebal $1 \mathrm{~mm}$ yang merupakan material sheeting pintu kereta api dan plat baja karbon SS400 tebal $3 \mathrm{~mm}$ profil $\mathrm{C}$ yang merupakan material frame pintu kereta api pada gambar 1. Material filler yang digunakan dalam pengelasan adalah ER70S-2.

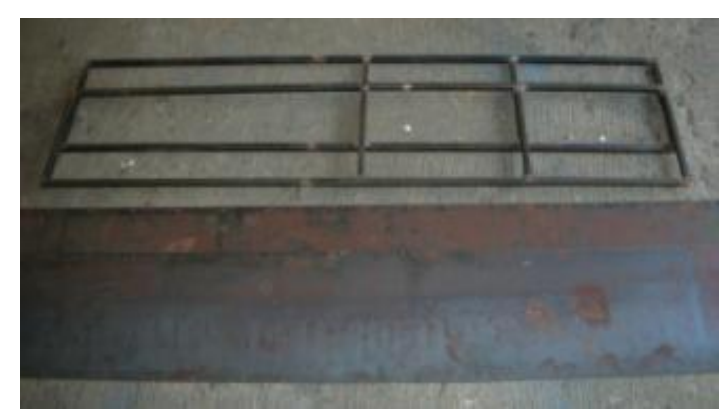

Gambar 1. Bahan Pintu Kereta Api.

Metode Las yang digunakan adalah las GMAW (Gas Metal Arc Welding) dan jenis sambungan sheeting-frame adalah sambungan plug welding (las isi). Plat sheeting diberi lubang dengan diameter $8 \mathrm{~mm}$ dengan jarak $100 \mathrm{~mm}$. Lubang ini yang akan menjadi sambungan dengan material frame.

Proses stressed sheeting weld dilakukan dengan mesin penarik dengan menggunakan regangan awal 0,3\% dan variasi temperatur preheat temperatur ruang $\left(27^{\circ} \mathrm{C}\right), 50^{\circ} \mathrm{C}, 60^{\circ} \mathrm{C}$ dan $70^{\circ} \mathrm{C}$.

\subsection{Karakterisasi Sambungan Las Pengujian Distorsi}

Pengukuran distorsi hasil las dilakukan dengan menggunakan dial indicator pada gambar 2. Pintu kereta api yang sudah dilas dibuat mesh dengan ukuran $5 \mathrm{~cm} \times 5 \mathrm{~cm}$ kemudian diukur kerataannya.

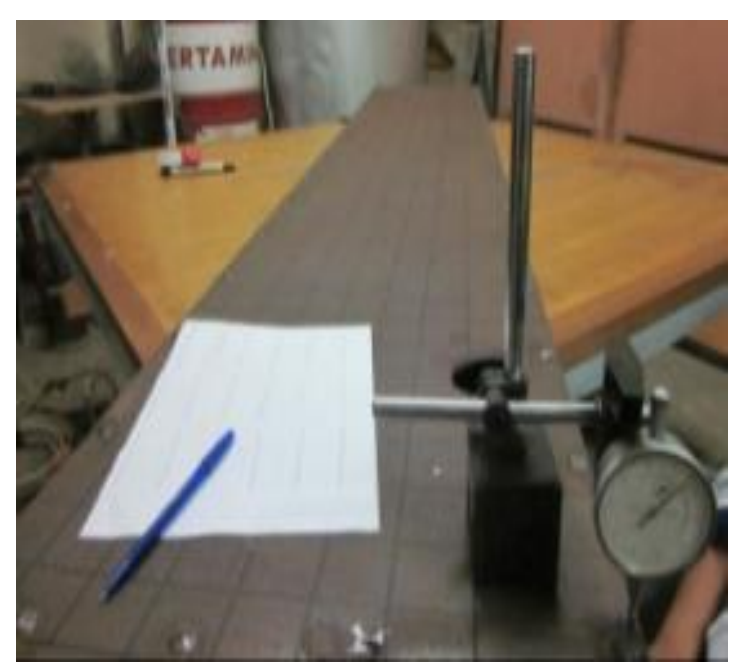

Gambar 2. Pengujian Kerataan. 


\subsection{Pengujian Tarik}

Pengujian tarik dilakukan untuk mengetahui kekuatan sambungan las (weld joint). Spesimen uji tarik mengacu pada standar French Standard A87-001, dengan dimensi spesimen seperti terlihat pada gambar 3. Setiap variasi pengelasan dilakukan 5 kali pengujian tarik.

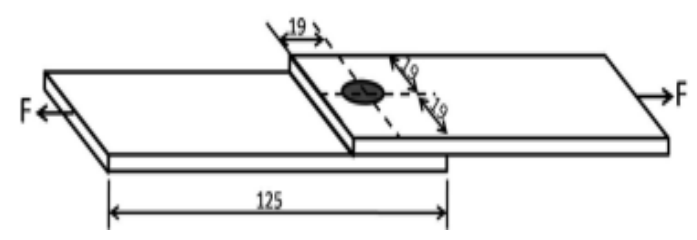

Gambar 3. Dimensi Spesimen Tarik.

\subsection{Pengamatan Fotomikro dan Fotomakro}

Pengamatan fotomikro dilakukan dengan mikroskop optic pada gambar 4 dengan menggunakan pembesaran $200 \mathrm{X}$. Sedangkan pengamatan fotomakro dilakukan dengan menggunakan stereozoom pada gambar 5.

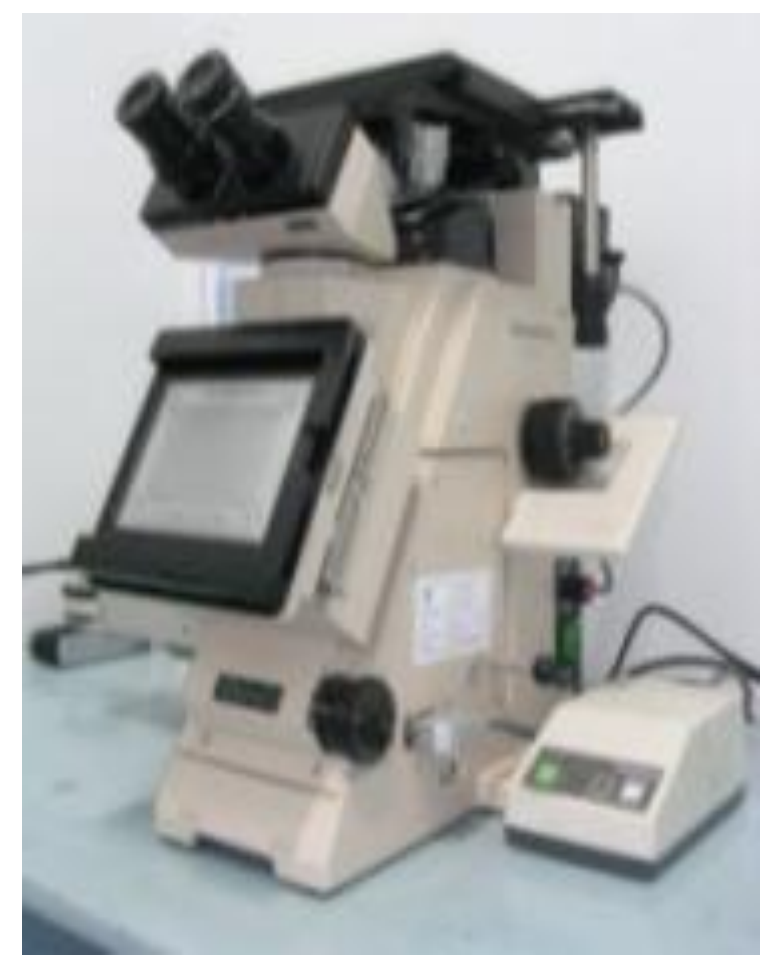

Gambar 4. Mikroskop Optik.

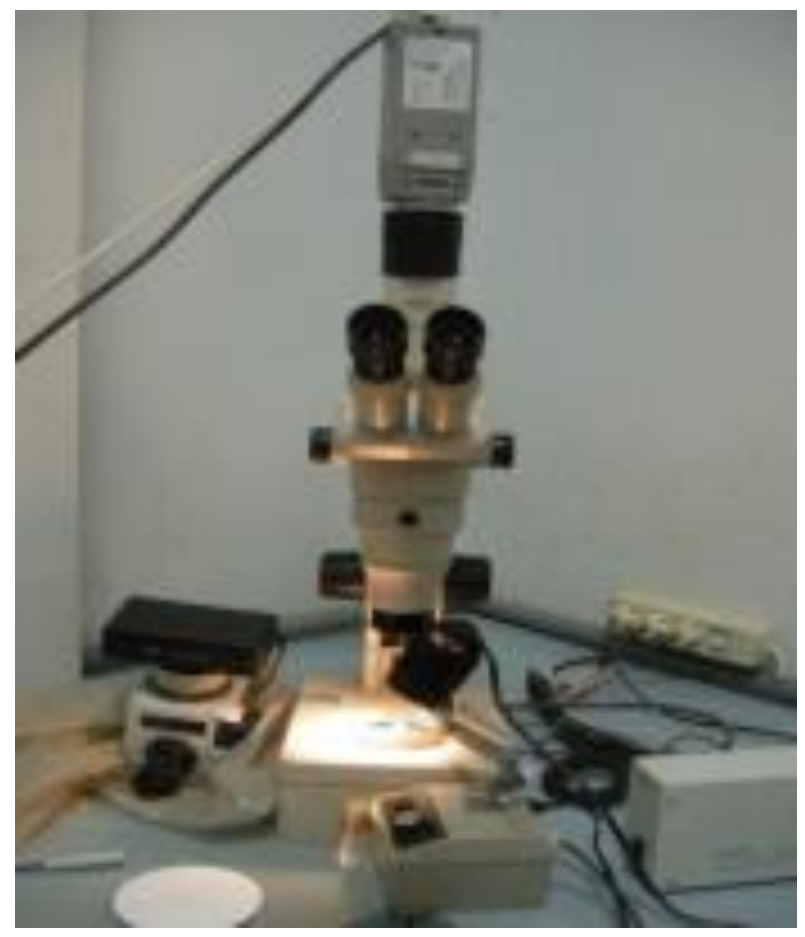

Gambar 5. Stereozoom.

\subsection{Pengujian Kekerasan}

Pengujian kekerasan dilakukan dengan menggunakan metode Vickers Microhardness dengan menggunakan beban 200grf.

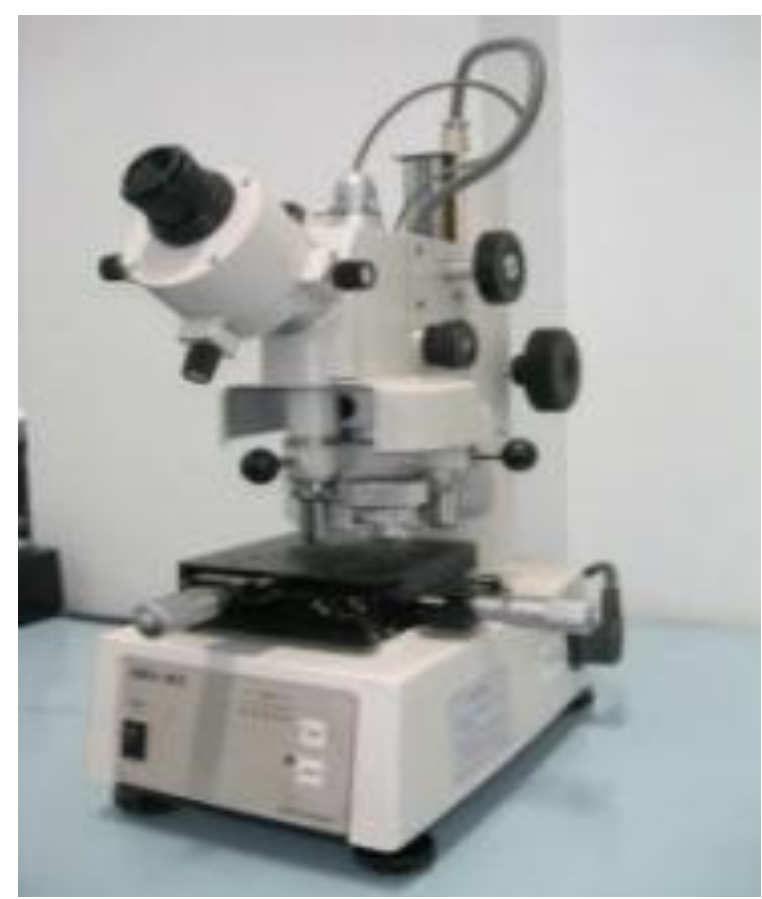

Gambar 6. Vickers Microhardness. 


\section{HASIL DAN PEMBAHASAN}

\subsection{Perancangan, perakitan pengembangan metode Stress Sheeting Weld}

Alat untuk pengembangan metode SSW meliputi meja terlihat pada gambar 7 dan mesin penarik pada gambar 8 .

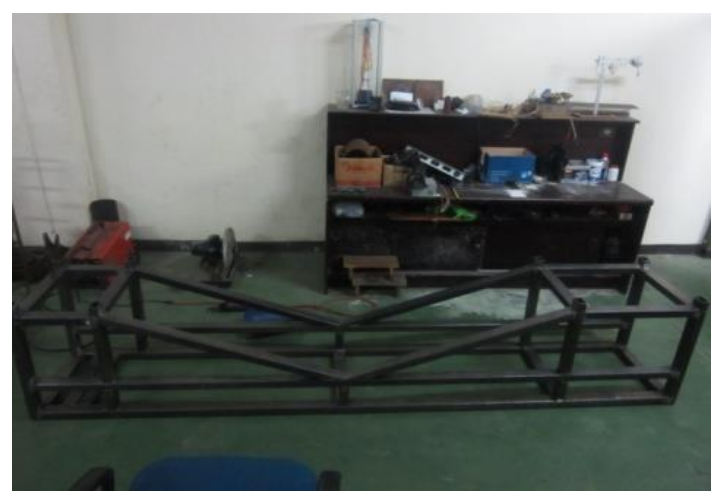

Gambar 7. Gambar Meja Dudukan Mesin Penarik.

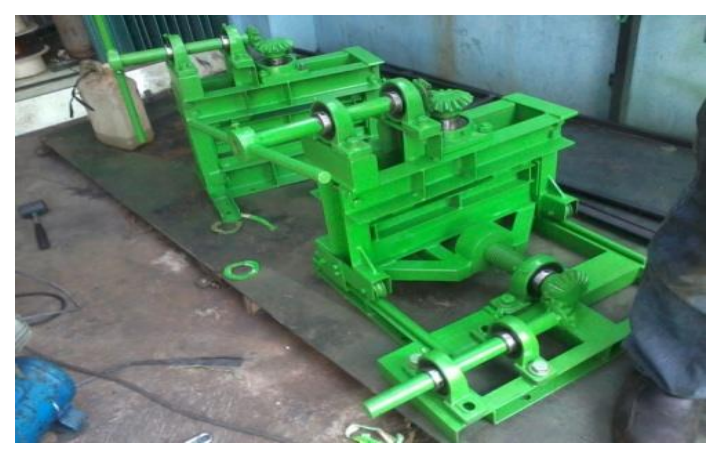

Gambar 8. Foto Mesin Penarik.

\subsection{Perancangan dan pembuatan Heater}

Heater terdiri dari pemanas dan alat monitoring suhu. Kedua alat tersebut telah selesai dibuat. Heater terlihat pada gambar 9 sedangkan alat monitoring suhu terlihat pada gambar 10 .

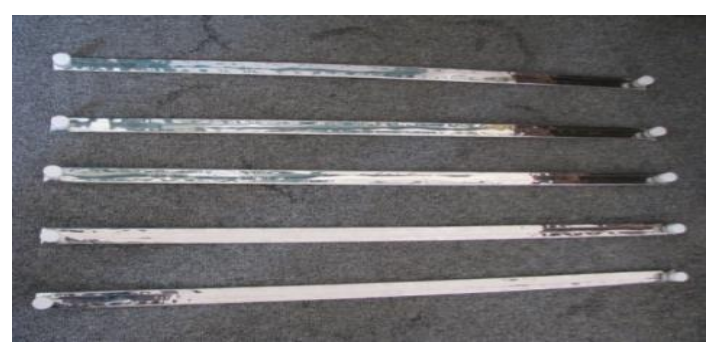

Gambar 9. Heater.

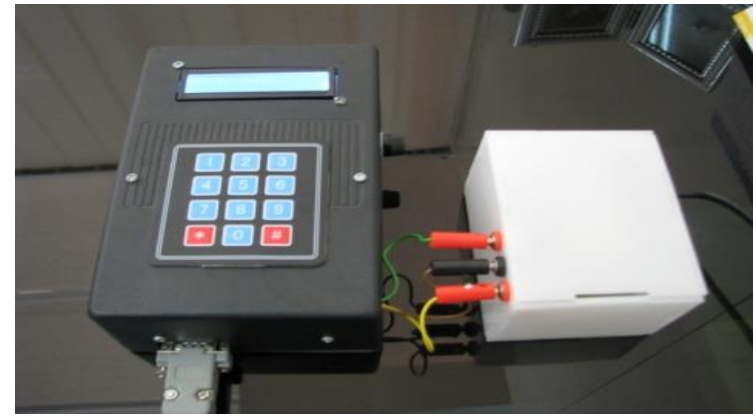

Gambar 10. Alat Monitoring Suhu.

\subsection{Pengujian Heater dan Alat Monitoring Suhu}

Pengujian dilakukan untuk mengukur temperatur pada beberapa bagian material pintu yang akan dilas. Jarak tiap titik pengukuran adalah $20 \mathrm{~cm}$. Pengujian dilakukan dengan menggunakan thermocouple dan alat pengukur panas infrared. Hasil pengujian dapat dilihat pada tabel 1 .

Tabel 1. Hasil Pengujian Heater

(Purwaningrum, dkk, 2012)

\begin{tabular}{|c|c|c|}
\hline No & Bagian Atas (A) & Bagian Bawah (B) \\
\hline \multicolumn{3}{|c|}{ Setting Alat: $70^{\circ} \mathrm{C}$} \\
\hline 1 & 69.5 & 70.6 \\
\hline 2 & 71.6 & 70.7 \\
\hline 3 & 64.0 & 69.5 \\
\hline 4 & 71.2 & 69.6 \\
\hline 5 & 71.2 & 65.5 \\
\hline 6 & 66.0 & 66.5 \\
\hline \multicolumn{3}{|c|}{ Setting Alat: $60^{\circ} \mathrm{C}$} \\
\hline 1 & 54.7 & 57.7 \\
\hline 2 & 68.0 & 60.7 \\
\hline 4 & 53.3 & 59.5 \\
\hline 4 & 55.0 & 59.5 \\
\hline 5 & 66.5 & 59.6 \\
\hline 6 & 52.5 & 53.7 \\
\hline \multicolumn{3}{|c|}{ Setting Alat: $50^{\circ} \mathrm{C}$} \\
\hline 1 & 50.2 & 52.8 \\
\hline 2 & 47.2 & 52.8 \\
\hline 3 & 44.5 & 48.0 \\
\hline 4 & 48.5 & 47.3 \\
\hline 5 & 42.7 & 55.0 \\
\hline 6 & 53.0 & 46.2 \\
\hline
\end{tabular}


Dari hasil pengukuran temperatur dan perhitungan secara statistik didapat hasil ketepatan adalah $97.06 \%, 93.10 \%$ dan $93.43 \%$ untuk setting temperatur $70^{\circ} \mathrm{C}, 60^{\circ} \mathrm{C}$ dan $50^{\circ} \mathrm{C}$.

\subsection{Pengujian Hasil Pengelasan Pengujian Distorsi}

Dari hasil pengujian 387 titik pada tiap spesimen dan setelah dihitung dengan statistika maka didapat nilai rata - rata distorsi hasil pengelasan dengan variasi temperatur preheat seperti pada gambar 11 .

Hasil pengujian menunjukkan bahwa pemberian temperatur preheat akan mengurangi distorsi pada hasil pengelasan. Nilai distorsi terendah terdapat pada hasil las dengan temperatur preheat $50^{\circ} \mathrm{C}$ yaitu dengan nilai $1.07 \mathrm{~mm}$. Nilai ini menunjukkan distorsinya kurang dari $50 \%$ jika dibandingkan hasil las tanpa preheat.

Sedangkan pada temperatur $60^{\circ} \mathrm{C}$ dan $70^{\circ} \mathrm{C}$, nilai distorsi-nya cenderung naik. Hal ini disebabkan karena temperaturnya lebih tinggi tetapi regangan awal yang dipakai sama sehingga terjadi ketidakrataan yang cukup tinggi.

Akan tetapi jika dibandingkan dengan metode yang digunakan sekarang, yang menghasilkan nilai ketidak rataan $3.02 \mathrm{~mm}$, maka pengembangan metode stressed sheeting weld dengan variasi preheat cukup efektif untuk menurunkan nilai ketidakrataan pada hasil pengelasan.

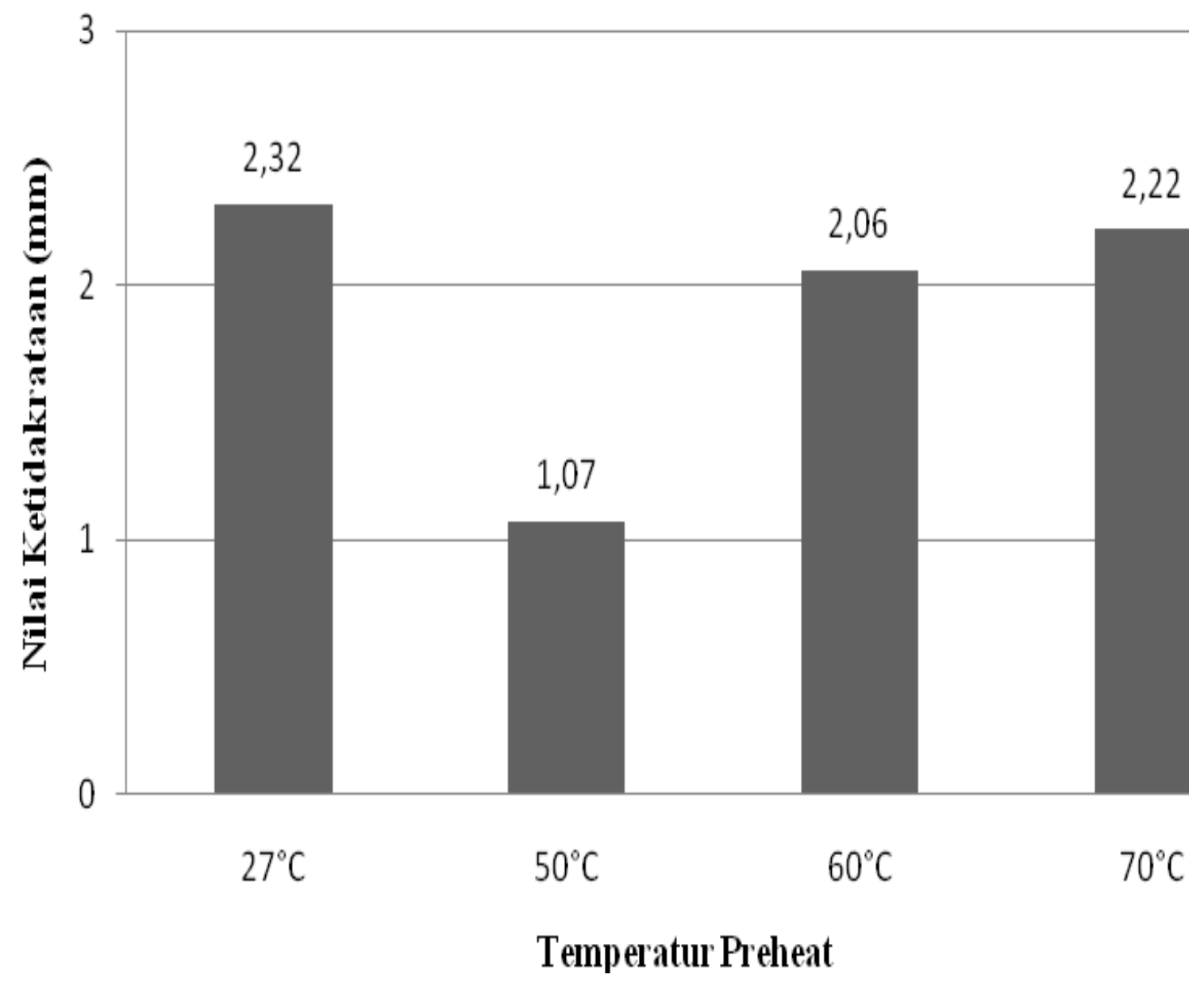

Gambar 11. Nilai Distorsi Hasil Las. 


\subsection{Pengujian Tarik}

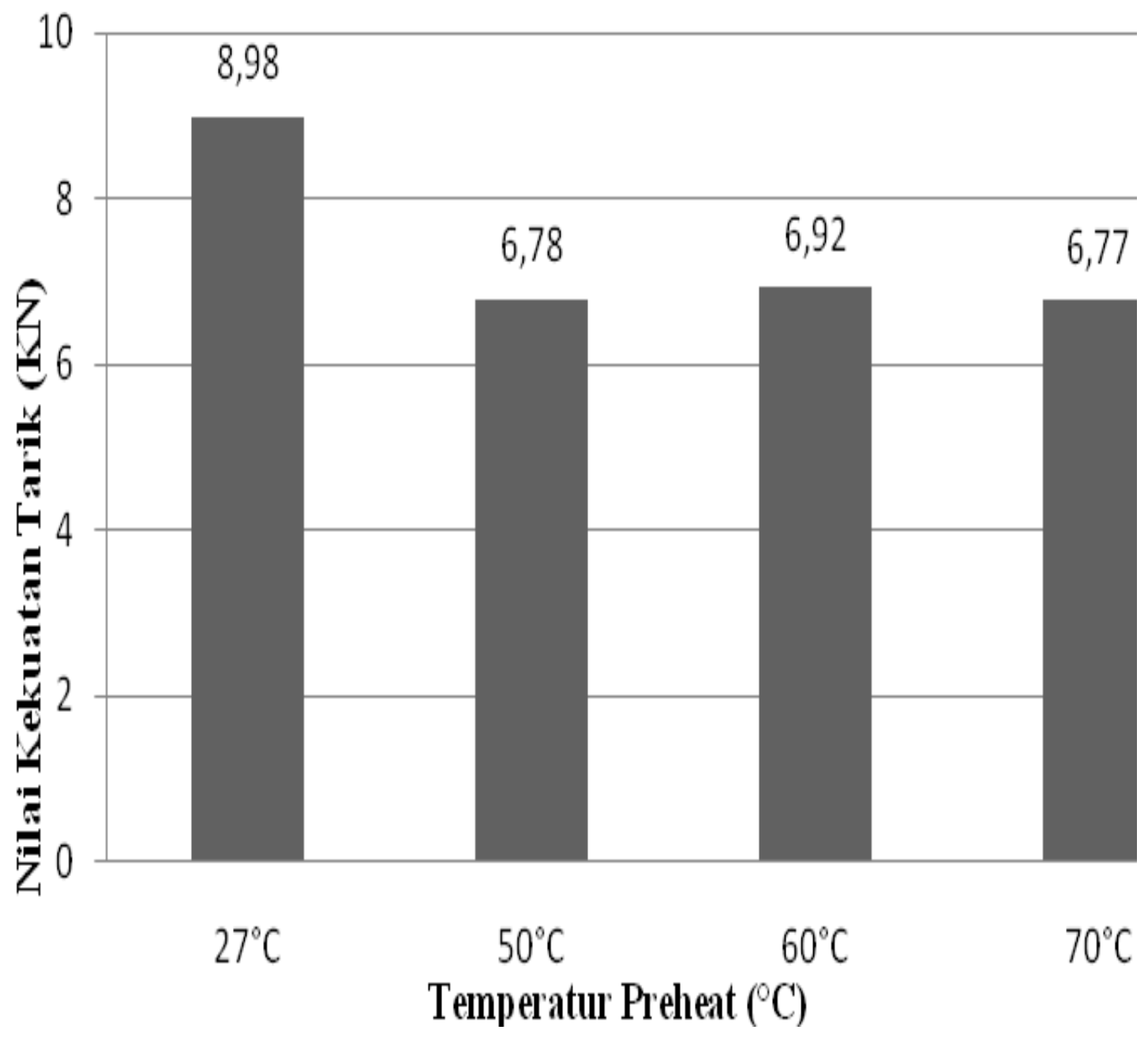

Gambar 12. Grafik Hasil Pengujian Tarik

Gambar 12 menunjukkan hasil pengujian tarik. Kekuatan tarik tertinggi pada hasil las tanpa pemanasan dengan nilai $8.98 \mathrm{KN}$.

Sedangkan untuk variasi $50^{\circ} \mathrm{C}, 60^{\circ} \mathrm{C}$ dan $70^{\circ} \mathrm{C}$, masing-masing mempunyai nilai rata rata $6.78 \mathrm{KN}, 6.92 \mathrm{KN}$, dan $6.77 \mathrm{KN}$.
Semua hasil pengujian dengan menggunakan pengembangan metode stressed sheeting weld dengan variasi temperatur preheat mempunyai nilai yang lebih tinggi dibandingkan metode yang digunakan saat ini. Nilai rata - rata kekuatan tarik tanpa metode stressed sheeting weld adalah $5.58 \mathrm{KN}$. 


\section{Pengamatan Fotomakro}

Tabel 2. Fotomakro Hasil Pengelasan.

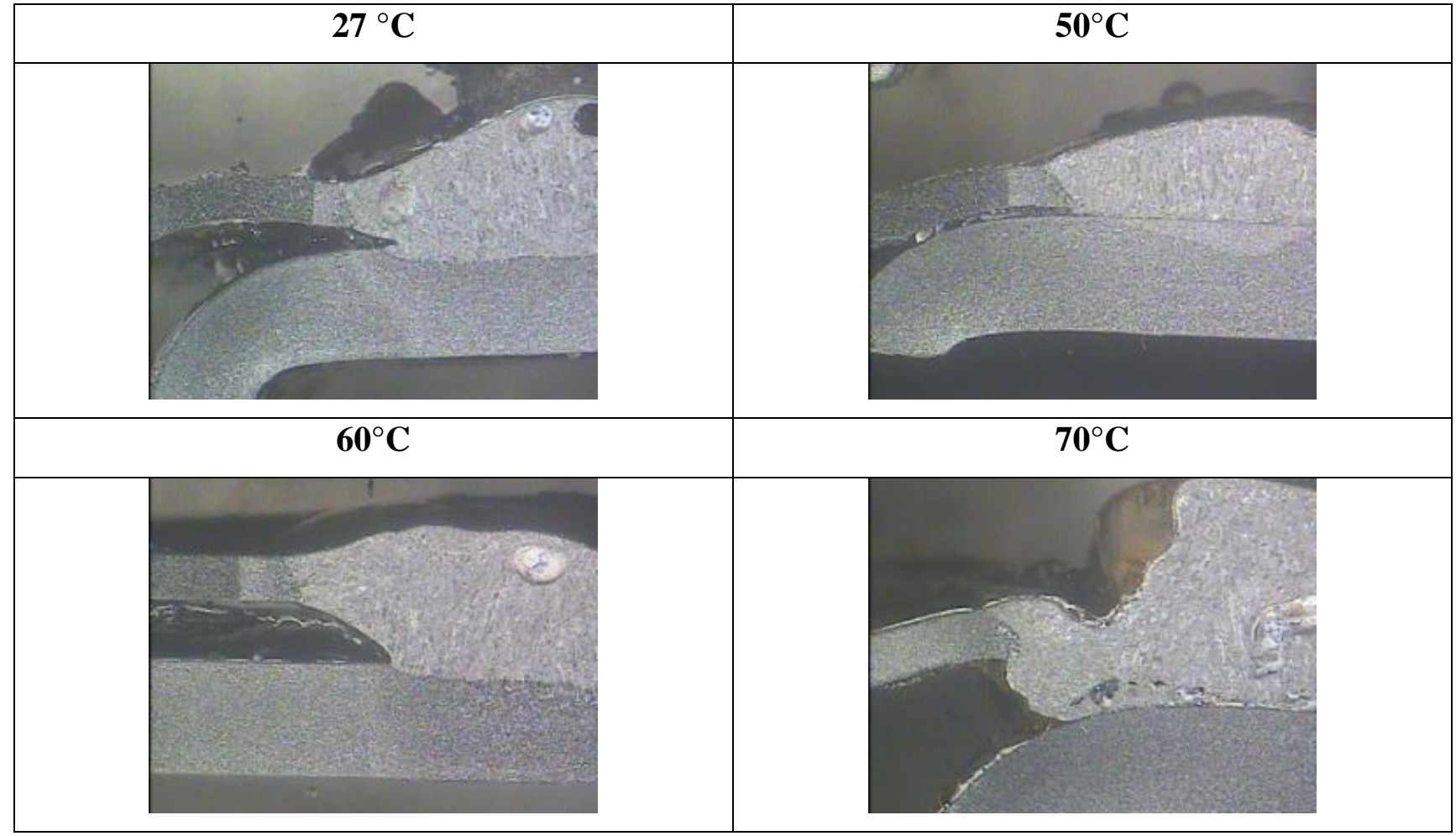

Pengamatan fotomakro dilakukan dengan menggunakan pembesaran 9x. Hasil pengamatan fotomakro ditunjukkan oleh gambar tabel 2. Dari tabel terlihat bahwa sambungan antara frame dan plat untuk semua variasi pengelasan cukup bagus Dari fotomakro terlihat hasil pengelasan dapat dibagi menjadi tiga daerah yaitu : logam induk, daerah HAZ (Heat Affected Zone) dan daerah Las.

\subsection{Pengamatan Fotomikro}

Tabel 3 adalah tabel struktur mikro hasil pengelasan dengan variasi temperatur preheat. Struktur mikro hasil pengelasan relatif sama untuk semua variasi hasil pengelasan yaitu berupa ferit dan perlit pada logam induk. Untuk daerah HAZ struktur mikro yang terbentuk adalah ferit dan perlit tetapi ukurannya lebih kecil. Ferit adalah struktur mikro yang berwarna terang sedangkan perlit berwarna lebih gelap.
Perbedaan ukuran pada kedua daerah ini disebabkan karena adanya pengaruh panas las. Sedangkan untuk daerah las, struktur mikro yang terbentuk adalah ferit acicular dan ferit batas butir. Struktur mikro tersebut terbentuk karena panas pengelasan pada daerah ini telah melewati titik kritis dan pada daerah ini terdapat penambahan filler. 
Tabel 3. Struktur Mikro Hasil Las dengan Variasi Temperatur Preheat.

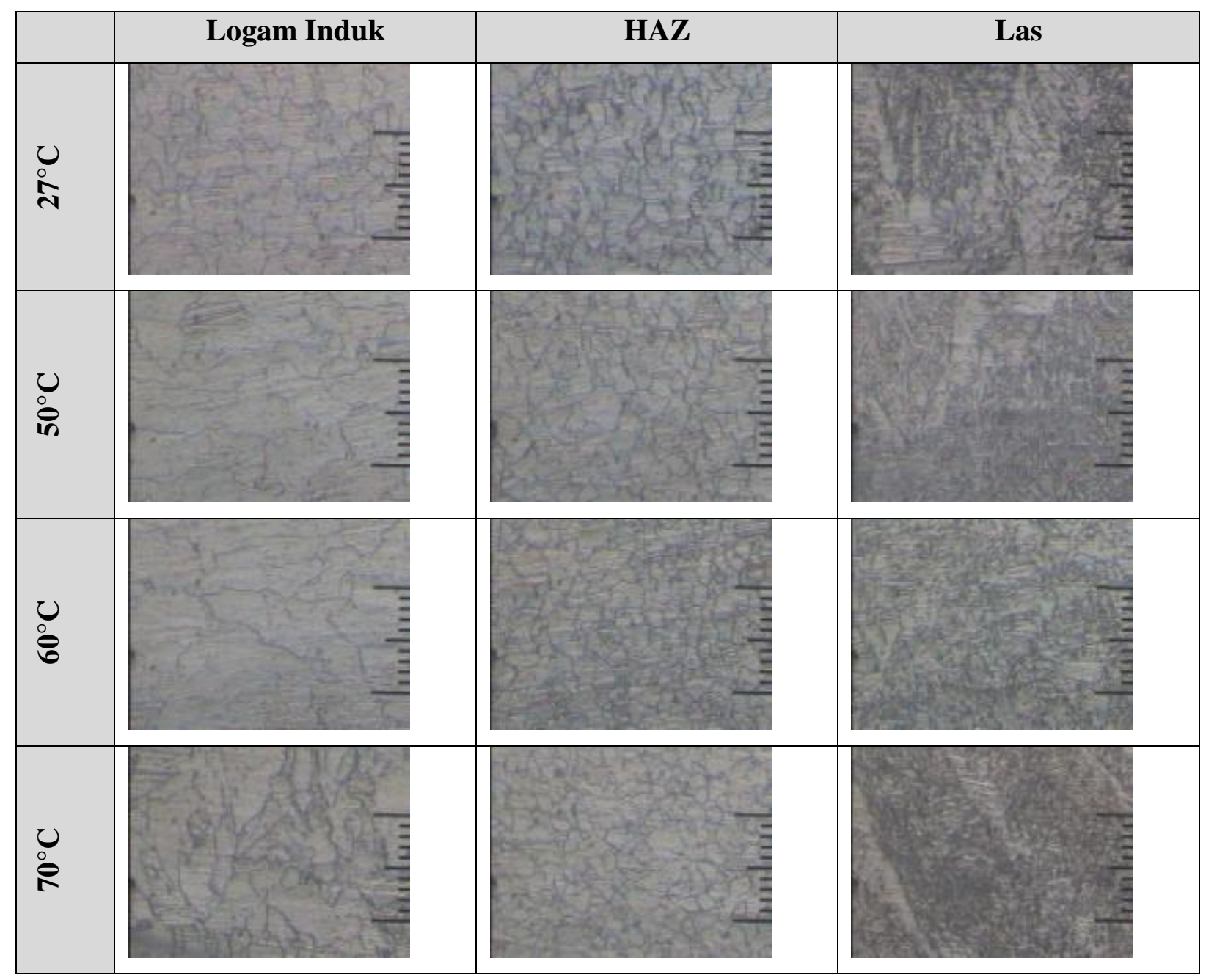

\subsection{Pengujian Kekerasan}

Pengujian kekerasan dilakukan dengan jarak $2 \mathrm{~mm}$ antar titik. Hasil pengujian kekerasan hasil las dapat terlihat pada gambar 13.

Hasil pengujian menunjukkan kecenderungan grafik yang sama pada semua variasi. Pada daerah las (posisi 0) nilai kekerasan cenderung rendah karena pada daerah ini struktur mikro yang terbentuk berupa ferit Accicular dan ferit batas butir. Sifat dari struktur ini adalah ketangguhan tinggi tetapi kekerasannya rendah.

Pada daerah HAZ (posisi 2 sd 10) nilai kekerasannya paling tinggi jika dibandingkan dengan daerah lainnya. Pada daerah ini terkena pengaruh panas pengelasan tetapi temperatur pada daerah ini tidak mencapai temperatur kritisnya.

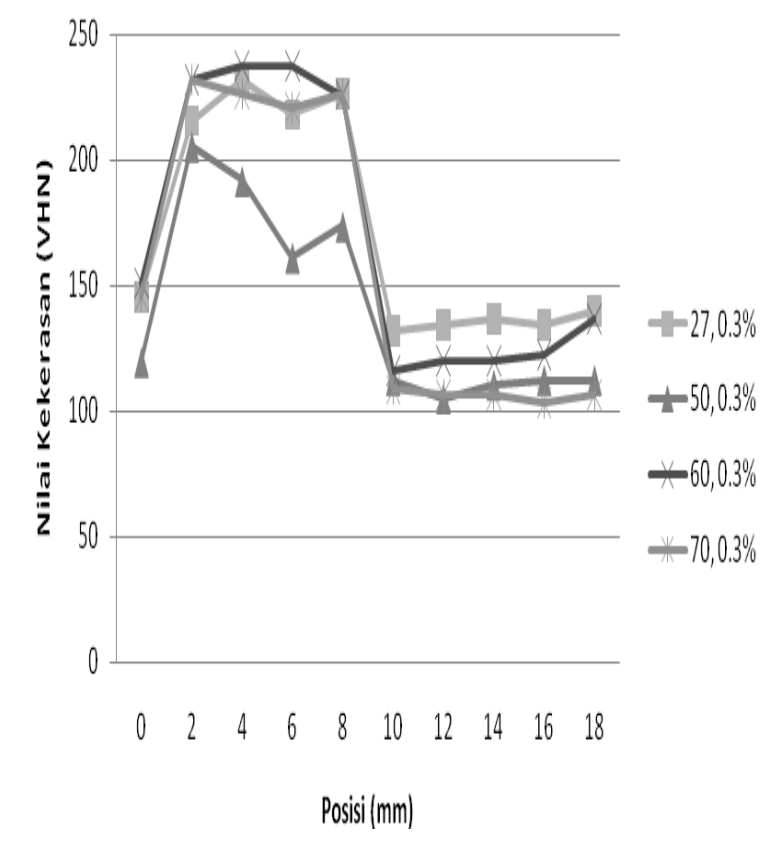

Gambar 13. Nilai Kekerasan Hasil Las dengan Variasi Temperatur Preheat. 


\section{KESIMPULAN}

Dari hasil penelitian dapat disimpulkan:

1. Mesin penarik untuk mengembangkan metode Stressed Sheeting Weld telah selesai dibuat dan dapat digunakan dengan baik.

2. Heater dan alat monitoring suhu untuk memanaskan material sebelum pengelasan telah selesai dibuat dan dapat digunakan dengan baik.

3. Proses pengelasan telah dilakukan, baik dengan variasi temperatur preheat maupun variasi regangan awal. Temperatur preheat yang digunakan adalah $50^{\circ} \mathrm{C}, 60^{\circ} \mathrm{C}$ dan $70^{\circ} \mathrm{C}$.

4. Hasil pengujian distorsi menunjukkan bahwa semua hasil las dengan pengembangan metode SSW mempunyai nilai lebih kecil jika dibandingkan tanpa SSW.

5. Nilai kekuatan tarik hasil las dengan menggunakan pengembangan metode stressed sheeting weld dengan variasi temperature preheat dan regangan awal mempunyai nilai yang lebih tinggi dibandingkan metode yang digunakan saat ini. Nilai rata - rata kekuatan tarik tanpa metode stressed sheeting weld adalah $5.58 \mathrm{KN}$, sedangkan hasil las pengembangan mempunyai rata - rata nilai terendah $6.39 \mathrm{KN}$ dan nilai rata - rata tertinggi $8.98 \mathrm{KN}$.

6. Struktur mikro hasil las pada daerah logam induk dan HAZ adalah ferit dan perlit. Sedangkan pada daerah las adalah Ferit acicular dan ferit batas butir.

7. Nilai kekerasan tertinggi terdapat pada daerah HAZ. Karena struktur mikro daerah ini ukurannya lebih kecil dibandingkan dengan logam induk.

\section{UCAPAN TERIMA KASIH}

Peneliti mengucapkan terima kasih kepada DIKTI atas diberikannya Hibah Bersaing dengan kontrak No. 26 / Dir / DPPM / 70 / Hibah Bersaing - DIKTI / V 2013 sehingga penelitian ini dapat berjalan dengan baik.

\section{DAFTAR PUSTAKA}

Deo, M. V., dan Michaleris, P., 2002, Mitigation of Welding Induced Buckling Distortion Using Transient Thermal Tensioning, Science and Technology of welding and Joining.

Dull R.M., Dydo J.R., Russell J.J., and Shanghvi, J., 2005, Methode of Reducing Distortion by Transient Thermal Tensioning, US Patent no. 6861617.

Okano S., Mochizuki M. \& Toyoda M., 2006, Thermal Conductivity Theoretical Examination Concerning Characteristics of Welding Distortion Produced by Multiple Heat Sources : Studies on Welding Distortion Control by Temperature Distribution Control Using Multiple Heat Sources (Report 1), Quarterly Journal of The Japan Welding Society, Vol.24, No.4, pp. 324-330, ISSN:02884771.

Purwaningrum Y., Kusriyanto M., dan Triyono, 2012, Rancang Bangun Mesin Penarik untuk Pengembangan Metode Stressed Sheeting Weld, Prosiding Semnas Menuju Masyarakat Madani dan Lestari, 18 Desember 2012, Yogyakarta Hal.F659-666.

Radaj, D., 1992, Heat Effects of Welding, Springer-Verlag, Berlin.

Triyono, Diharjo, D., Ilman, M.N., Soekrisno, R., 2005, Pengaruh Flame Heating terhadap Ketahanan Korosi dan Sifat Mekanis Sambungan Las Logam Tak Sejenis sebagai Struktur Utama Gerbong Kereta Api, Laporan Hibah Pekerti III.

Wiryosumarto, Harsono, 2000, Teknologi Pengelasan Logam, Pradnya Paramita, Jakarta. 